\title{
Digital Social Networks as an Innovation Strategy in Tourism Businesses
}

\author{
ISAAC CRUZ ESTRADA \\ Strategic Planning for Performance Improvement Ph. D., \\ Professor at Universidad Autónoma de Baja California. \\ Email: icruz@uabc.edu.mx
}

MARTHA OFELIA LOBO, RODRÍGUEZ

Economics Ph. D., professor at Universidad Autónoma de Baja California.

Email: mlobo@uabc.edu.mx

CARLOS ALBERTO FLORES SÁNCHEZ

Economics Ph. D., professor at Universidad Autónoma de Baja California.

Email: cflores@uabc.edu.mx

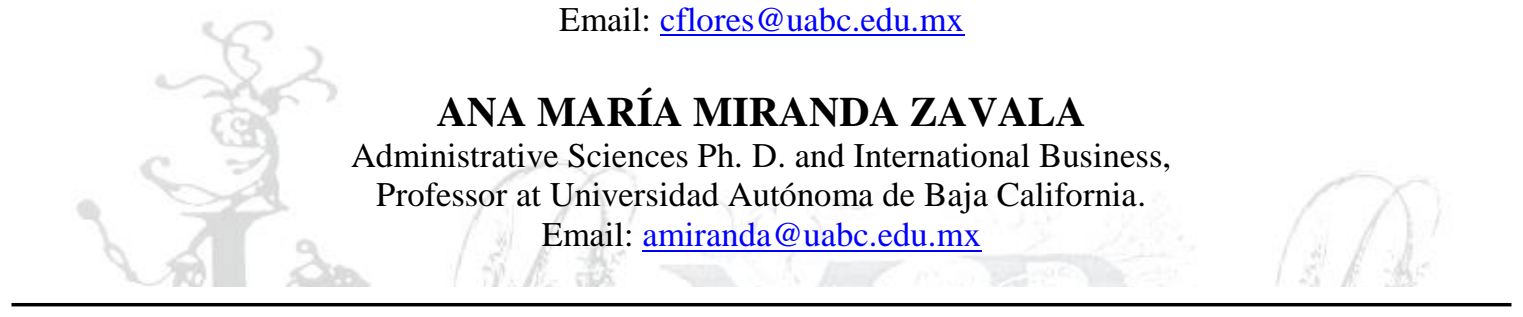

\section{ANA MARÍA MIRANDA ZAVALA}

Administrative Sciences Ph. D. and International Business,

Email: amiranda@uabc.edu.mx

\begin{abstract}
More and more people are turning to digital media to learn about the benefits offered by tourism services, and this becomes a factor when making a decision. The aim of this research is to analyze the relationship between social networking strategies and the consumers' intention of buying from tourism businesses. For the purpose of this research, the subjects of study are customers from five restaurants located in the gastronomic zone of Tijuana, Baja California, Mexico. Tourism businesses were selected through the observation technique, which allowed identifying those with constant activity in their social networks. 378 surveys were applied, and they were distributed based on the average number of diners reported by the managers of each organization. The results show that the Internet is the medium most used by consumers when searching for services; likewise, the social network preferred by respondents while searching for restaurants is Facebook. It was also shown that there is an average correlation between social networks strategies and the purchase intention. In this way, it is necessary to implement a digital strategy as part of the corporate business project to achieve the desired impact. Through the experience gained, the strategy can be adapted to the needs exposed by Internet users. The process should be clear about the goals expected in agreement with the necessary resources for the success of the project.
\end{abstract}

Keywords: Innovation, Social Networks, Strategy, Purchase Intention, Tourism.

\section{Introduction}

The emergence of new media in recent years favors the production of content in digital media by people using this technology; this scenario led to various changes in consumer behavior that caused the emergence of new types of tourism, specialists in the area, creation of strategies, digital marketing, information search 
tools, geolocation, social networking, among others (Mendes, Augusto, and Gândara, 2013; Altamirano, Tuñez, and Valarezo, 2016).

The need to search for information and the desire for sharing it among Internet users have contributed to the birth of various virtual communities that become benchmarks in the purchase decision of a touristic product. Altamirano et al (2016), Sixto (2015), Miranda and Cruz (2016) assure that these groups, in most cases, are created independently and not through the work of organizations, so companies must be attentive to the behavior of their audience in order to work on current market trends.

Thus, social networks have managed to become a tool used by consumers because they can be helpful while planning a trip and choosing the places to visit during the stay. Nowadays, it is the consumers themselves who advertise on Internet the best destinations and services that have managed to meet their needs. The incessant interaction between members of the virtual community has become one of the most influential phenomena in recent years (Azuela-Flores, 2011; Uribe, Rialp, and Llonch, 2013; GonzalezValiente, 2014).

Thereby, the aim of the research is to analyze the relationship between strategies with social networks and the consumers' intention of buying from tourism businesses. In this case, consumers from five restaurants in the gastronomic zone of Tijuana, Baja California, are presented as subjects of study. The tourism businesses were selected through the observation technique, which identified those with constant activity in their social networks in order to attract the information and conclusions that can be useful for organizations that perform digital marketing initiatives as part of the corporate strategy.

\section{Literature Review}

The Internet digitalization to which people are exposed influences them to stop being recipients of information and become active participants in the Web. Researchers (Herrera, 2009; Hütt, 2012; Leal and Porras, 2015) assure that technology has evolved to enable individuals to produce their own content and share their experiences, which has led to significant growth in the usage of social networks by companies as a way to promote products and services and to manage the relationships with current customers more efficiently.

Social networks have become a global phenomenon, much of the population of different social generations has found a way to get information on tourism products and / or services that they will consume on their next opportunity. Through these technologies, it is possible to access various alternatives and to learn about their characteristics and present offer on the market (Gutierrez-Leefmans and Nava-Rogel, 2016; OMT, 2016).

Through the ministerial summit of the World Tourism Organization (UNWTO) and the World Travel Market (WTM), ministers and private sector managers agreed that the branding of destinations and operation of companies oriented to tourism marketing need to adapt to changes induced by social networks, as the empowerment of consumers of these digital tools has completely transformed the way of making strategies that impact positively on the companies and the image of the destination (SEGITTUR, 2015; UNWTO, 2015).

\section{The Innovation of Strategies through Digital Social Networks in Tourism.}

The trend in tourism communication through digital media in Latin America is evident. Government agencies that promote tourism procure general social networks among which are Facebook, Twitter, YouTube, Instagram, Pinterest, Google+, Flickr as part of the management strategies for customer relations in order to provide information and create a channel with their audience with the intention to achieve 
immediacy and accessibility (Ruano, Congote, and Torres, 2016; Santillan-Nuñez, Velarde-Valdez and Obombo-Magio, 2015; Altamirano et al, 2016).

Some organizations that have refused to technological change have seen their share of the tourism market diminished. Researchers (Buhalis and Law, 2008; Santillan-Nuñez et al, 2015; Pinto de Farias et al, 2017), affirm that the success of the digital age is related to the flexibility and visibility. In this sense, it is common that tourism businesses that adapt to this dynamic occupy the best competitive market spaces. The efficiency of digital services requires to pay greater attention to consumer behavior and take advantage of the benefits of communicating with customers.

The tourist today has become an avid consumer of landscapes, experiences, and imaginary narratives. Pinto de Farias, Costa and Costa-Perinotto (2017), and SECTUR (2016) claim that without the inclusion of technology available on the Internet, organizations are less likely to succeed in the tourism market. The usage of certain platforms interconnected with social networks is increasing and has become a structural factor for competitiveness and impact on the tourism industry.

The mere presence of companies and / or tourist destinations on the Web is not enough. The important thing is to take action to avoid static positions, favoring online interaction and collaboration that will allow users to generate and share experiences, forming part of the virtual community and becoming content generators (Farias, 2014; Daries-Ramon et al, 2016). In addition, further work will involve maintaining all the information generated, in order to convey confidence to people who are aware of what is being published in different digital platforms.

Based on the results of the study by Miranda and Cruz (2016), the top five main attributes that social networks must have, in the case of hotels are: location, prices of services, promotions information, restaurant service information, and information on the hotel category. This demonstrates the anticipated need for attention and benefits that people wish to enjoy at the time of their visit.

Showing that the company is present and innovative is one of the main reasons why managers of large and small corporations decide to bet on digital platforms like Facebook, Twitter or LinkedIn, among others. SEGITTUR (2015, Giraldo and Martinez (2017) assure that the above is not enough and we must opt for a strategy to promote as a fundamental principle to achieve efficient management of relations with the consumer and, as a consequence, the organizations will obtain the commercial benefits that they seek.

Internet has become a key to the livelihood of any business project in tourism. Since the scope of social networks is superior to conventional means caused by digitalization to which people are exposed, the tourist-consumer today wants to get tourism products that suit their individual needs, as he himself feels like part of the global network of computers (SEGITTUR, 2015; Andrade, 2016; Pinto de Farias et al, 2017).

Thus, the future of tourism should be approached with new perspectives focused on innovation and the adoption of Information and Communication Technology (ICT), taking advantage of the benefits of Internet in all its dimensions, not only as an element for promotion. It should also include commercialization, among which is the creation of storytelling, which leads to the online provision, reservation, and purchase of the tourism product or service that adds competitiveness to the destination and tourism organizations (Daries-Ramon et al, 2016; Prada, 2016; Aldape, Abrego, and Medina, 2016).

As result of the digitization to which consumers are exposed, companies are forced to make communication strategies among the same businesses, giving rise to mergers, reducing operating costs, market strategies that integrate a group of businessmen, among other needs. Abrego, Sanchez and Medina (2016), Valenzuela and Martinez (2015) warn that the mere investment in technological tools does not guarantee improved results, therefore, it is necessary to work on operational efficiency between partners and for 
information management to become innovative proposals for tourism products and services available to customers. Thus, Moliner, Fuentes and Gil (2014), Sarmiento (2016), and Prada (2016) claim that by using ICT, tourism businesses can achieve the following benefits: increasing internal efficiency; revolutionize the tourism intermediation that allows an increase in the number of outlets; extend the operational and geographical area offering strategies for global expansion; by using social networks, it is possible to interact effectively with users and customize the service, and it also facilitates and promotes cooperation between partners related to the organization.

One of the most important benefits achieved by using digital channels is the interaction in dealing with customers, which enables tourism businesses including hotel chains, restaurants, tour operators, among others, to improve their service by sharing the experiences expressed by individuals (Rodríguez, Fraiz, and Ramos, 2015; Coromoto and Coromoto-Morillo, 2016). This allows enhancing the brand image and building customer loyalty by providing feedback that adds value by rewarding the loyalty of the people who are frequent visitors, turning them into the main promoters of the services or products of tourism businesses.

\section{Purchase Intention through Digital Tools}

According to Moliner, Fuentes, and Gil (2014), Rojas and Redondo (2017), the main problems for businesses to assess the impact of social networks are the following: the definition of the waiting period required to receive the ROI, the cost estimate for the implementation of the strategy, and identifying the best way to measure the expected results. Each organization is a particular case; however, it depends on time and monitoring the strategic planning in order to obtain benefits. This is directly related to the nature and extent of absorption of the new technologies used by businesses for social networks and for digital and social marketing.

Notably, a strategy using digital tools must have guidelines to guide each of the phases considered in the organizational plan. The National Institute of Entrepreneurship (INADEM) in Mexico indicates that a plan with social networks should not start without a clear strategy and to avoid bad practices related to buying fake followers or likes to generate a reliable appearance to the public and to avoid sharing too many publications in a short period without a specific purpose (SEGITTUR, 2015; INADEM, 2017).

On the other hand, the website can be defined as the virtual face of the company, and the care and assertiveness of content is related to the success of this tool. The recommendations for the effectiveness of the main portal of the organization is that it must have a friendly appearance and ease of exploration, which allows it to be efficient for the user (Hütt, 2012; Miranda and Cruz, 2016; Andrade, 2016). Based on the authors, the key is to allow consumers to quickly identify the various options presented by the company, which are available to users, enabling them to effectively obtain the required information and, in some cases, the purchase of the products and services advertised.

With the emergence of social networks, the attention is on helping consumers before focusing on the purchase decision, since it is part of the process and even feedback and customer maintenance should be added, following up their experience, which consequently adds a new purchase and recommendation to others who rely on positive reviews based on the product or service purchased (Richardson et al, 2014; Rodriguez et al, 2015; Andrade, 2016). In Figure 1, the customer's decision-making process is presented (Business-to-consumer B2C) which shows the way social networks, blogs and other digital tools accessed by users manage to influence the decision of consumers.

Conventional marketing is based on analyzing the characteristics or elements that are important to meet the needs of customers. From the emergence of Web 2.0, customers seek information about the benefits of the product or service and enjoy doing this practice, because along the process they are adding value to the 
purchase they want to make. The excitement of the auction strategy has been a key element in the business model of companies like eBay (Richardson, Gosnay, and Carroll, 2014; Rojas and Redondo, 2017).

The scope and interaction of companies with their followers is extensive given the openness granted by social networks, ranging from having a feedback channel to using a space for promotion, information, and marketing. Furthermore, the possibility of having profiles, to which people can register friends, which leads to establishing a dynamic more focused on meeting the diverse needs and expectations of users (Hütt, 2012; Hayes, 2012; Rojas and Redondo, 2017).

Figure 1: The customer's decision process (B2C)

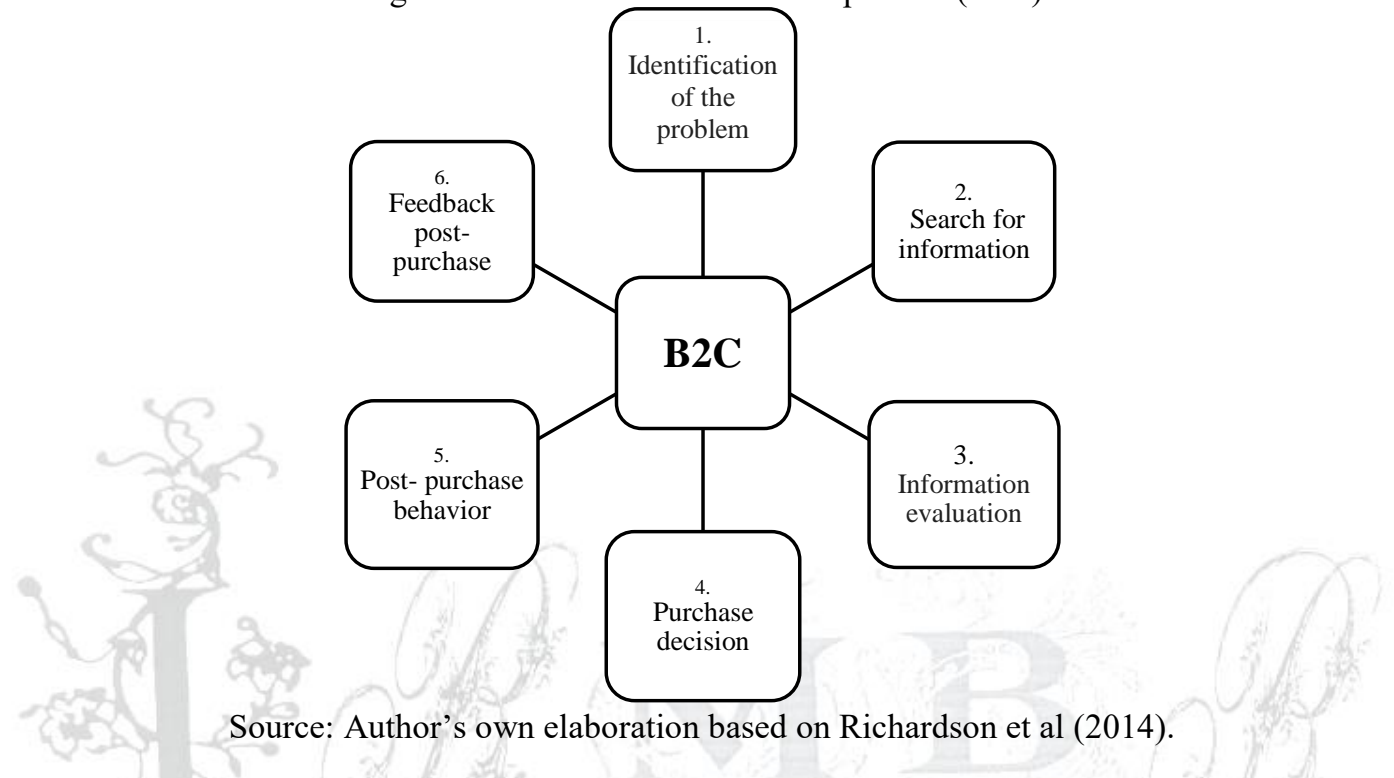

Internet has established as media and advertising support thanks to the penetration it has achieved in the world population. Castello (2013), Cruz and Miranda (2016) claim that this has influenced entrepreneurs to trust investing more in this medium in order to achieve a greater reach to consumers, therefore conveying the business identity and positioning its brand, so that it is present in the minds of users of social networks and other digital tools used in organizational strategies.

Customers also feel the need to showcase their consumption of intangibles, and they do it through a tool that allows them to materialize something as intangible as an experience using the social networks portal, commenting details that arouse interest in other people (Sarmiento, 2016; Andrade, 2016; Luna, 2017). Based on the authors, when individuals feel that there is a congruence between appearance and identity, they use social networks more intensely. Moreover, the consumer perceives the value of work done by organizations, which influences the desire to share information with other Internet users.

Thus in Table 1, some attributes and essential factors that increase confidence on the use of social networks are described, which manage to become key elements to increase purchase intention of users who access these digital media. Thus, it is essential to turn social networks into a reliable channel with certain characteristics that encourage their participation through a strategy characterized by meeting the essential areas of opportunity that companies need to attend.

Based on the authors cited in Table 1, social networking has become an element that contributes to the purchase intent. The increase in Facebook users, followers on Twitter, and other digital tools makes it necessary to take into account the inclusion of certain factors when setting your digital marketing strategy and configuring the tools designed for this purpose (Castello, 2013;. Miranda-Gonzalez et al, 2015; 
Sarmiento, 2016; Luna, 2017). People turn to these digital media for firsthand information broadcasting from the brands and even from influencers, those who are considered reliable, before deciding to purchase a product or service. Thus, the following hypothesis is presented as the basis of the work described in Figure 2 based on the theoretical approach developed.

H1. Strategies with digital social networks contribute to the intention of consumers to purchase from tourism businesses. For this case study, the subjects presented are consumers from five restaurants located in the gastronomic zone of Tijuana, Baja California. The units where surveys were conducted were selected because they showed activity in their social networks and answered questions about the services offered in their company. This allows to analyze the information collected and the relationship between the variables: social networking strategies and purchase intent.

Table 1: Essential attributes and factors of social networks

\begin{tabular}{|c|c|c|}
\hline Author & Major attributes of social network & $\begin{array}{l}\text { Factors that increase confidence and } \\
\text { security in the use of the social network }\end{array}$ \\
\hline $\begin{array}{l}\text { Izquierdo and Martinez, } \\
\text { 2009; Rojas et al, 2009; } \\
\text { SECTUR, 2014; Luna, } \\
\text { 2017; Miranda et al, 2015. }\end{array}$ & $\begin{array}{l}\text { Prices of services, corporate image, } \\
\text { customer services. }\end{array}$ & $\begin{array}{l}\text { Efficient communication, post-sale } \\
\text { service, warranty of the published } \\
\text { information. }\end{array}$ \\
\hline $\begin{array}{l}\text { Ruiz and Sanz, 2006; } \\
\text { Martinez-Valerio, 2012; } \\
\text { Martinez Bernal and } \\
\text { Mellinas, } 2012 .\end{array}$ & $\begin{array}{l}\text { Ease of access to information } \\
\text { available for customer service, } \\
\text { customer service instant messaging. }\end{array}$ & $\begin{array}{l}\text { Efficiency of the tools to learn about the } \\
\text { service or product. Response time by } \\
\text { customer service. }\end{array}$ \\
\hline $\begin{array}{l}\text { Martinez Bernal and } \\
\text { Mellinas, 2012; Miranda } \\
\text { and Cruz, 2016; } \\
\text { Miranda-González et al, } \\
\text { 2015; Sarmiento, 2016. }\end{array}$ & $\begin{array}{l}\text { Information on the type and quality } \\
\text { of the restaurant. Photography and } \\
\text { videos. Reservation service. } \\
\text { Registration on Google maps and } \\
\text { social networks for travelers. } \\
\text { Instant messaging. Option for } \\
\text { service evaluation. }\end{array}$ & $\begin{array}{l}\text { Links to organizations or groups of } \\
\text { entrepreneurs. Links to the official } \\
\text { website of the company. Quality of the } \\
\text { content. } \\
\text { Maintenance and follow-up of the } \\
\text { opinions shared by users. }\end{array}$ \\
\hline $\begin{array}{l}\text { Rojas et al, 2009; } \\
\text { Miranda-Gonzalez et al, } \\
2015 .\end{array}$ & $\begin{array}{l}\text { Information about services (prices, } \\
\text { promotions, wifi service, etc.). } \\
\text { Photographs of the service. Links to } \\
\text { business and / or government } \\
\text { organizations. }\end{array}$ & $\begin{array}{l}\text { Web design: attractive and harmony of } \\
\text { the published information, comfortable } \\
\text { feel. } \\
\text { Efficient handling of questions and } \\
\text { comments by the Community Manager }\end{array}$ \\
\hline
\end{tabular}

Source. Compiled from the works of the authors included in Table 1.

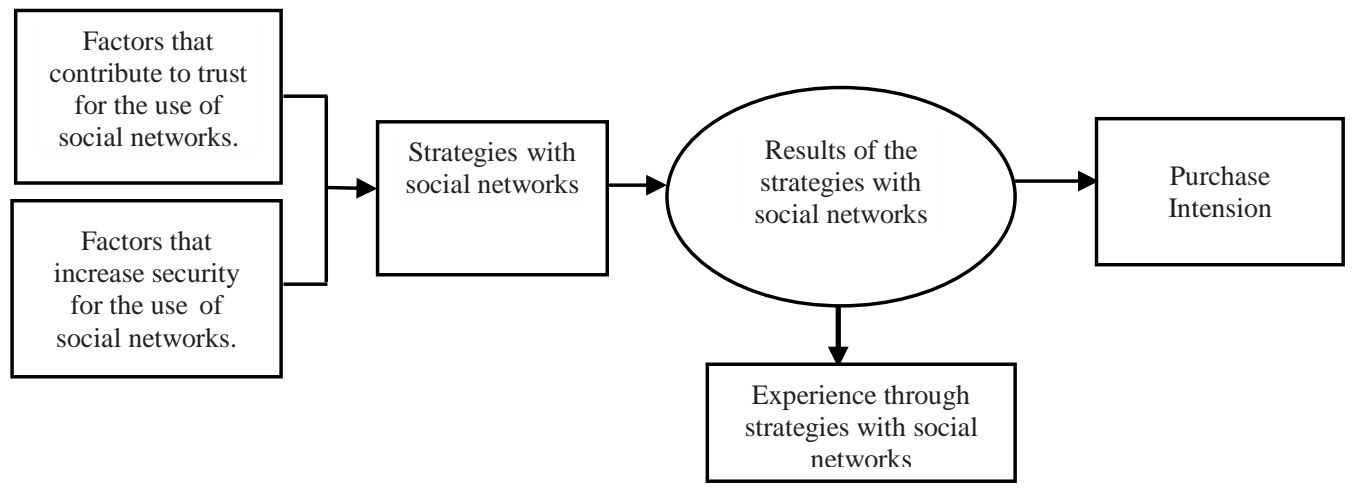

Figure 2: Purchase intention through social networking strategies.

Source: Author's own elaboration. 
The elements outlined in Figure 2 show that strategies with social networks require initiatives that become factors contributing to the confidence to use these digital media, resulting in the experience, which will accommodate the needs encountered during the process, thus influencing the purchase intention of people visiting these digital media, which then become the main promoters of the service received through the social network and after the product-consumption.

\section{Methodology}

The research method consists firstly on a review of literature for information based on the objective of the work, which is defined by acknowledging elements that contribute to the use of social networks, thus enhancing the consumers' purchase intent. In this sense, a quantitative survey method was used for the next phase of research, which is aimed at customers from five restaurants located in the gastronomic zone of the city of Tijuana, Baja California. Said restaurants were selected once observation was made on the Internet digital media used by the organizations in this area of the city, which have presence in social networks, are active, and answer questions about the services offered by their businesses, in order to apply the questionnaires to consumers who have had access to these digital tools.

Once the restaurants where the survey would apply were confirmed, permission was asked from the owners in order to conduct the research, taking into mutual agreement that the company name would be changed to a generic name in order to not affect the particular interests of each organization. This way, the monthly average amount of consumers was obtained from each business, in order to make the proportional allocation of instruments to be applied, from which the following data was obtained: Hornitos, 7,500; Villa 7,000; Kyaca, 3,330; Bienquerer, 2,000; Ginobles, 700; obtaining a total population of 20,530.

A formula for finite population was used (Fischer and Navarro, 2000), obtaining a sample size of 378 diners to survey, which were allocated to each organization by stratified sampling with proportional allocation (Namakforoosh, 2005). The distribution of this application is presented in Table 2.

\begin{tabular}{|c|c|c|}
\hline \multicolumn{3}{|c|}{$\begin{array}{l}\left.\text { Formula for proportional stratified sampling: } n i=n \frac{(\mathrm{Ni}}{\mathrm{N}}\right) \\
\qquad \text { Table 2: Survey application distribution }\end{array}$} \\
\hline Restaurants & No. diners per month & Instruments applied \\
\hline Hornitos & 7.500 & 138 \\
\hline Villa & 7.000 & 129 \\
\hline Kyaca & 3.300 & 37 \\
\hline Bienquerer & 2,000 & 61 \\
\hline Ginobles & 700 & 13 \\
\hline TOTAL & 20,530 & 378 \\
\hline
\end{tabular}

Source. Author's own elaboration.

This way, taking into account the contribution of the authors cited in the literature review in the survey, four dimensions were formed, presented in Table 3, that include questions ranging from knowledge of social networks used by respondents, seeking information about restaurants and how often this this activity is performed, attributes, elements that increase trust and confidence for the use of these restaurants' tools, and the influence they have on the purchase decision. 
Table 3: Dimensions of the survey applied to consumers

Knowledge and frequency of the social networks that consumers use to find information about restaurants that they usually attend.

Evaluation of attributes that must be present in social networks.

Assessment of factors that increase trust and confidence in consumers using the restaurant's social networks.

Importance of social networks in the purchase decision of consumers.

Source. Author's own elaboration.

Thus, the alpha coefficient of Cronbach is shown with the dimensions described in Table 4, in order to present the reliability of the survey applied to consumers from the restaurants. By using the statistical tool SPSS20, good reliability resulted from the instrument used in the research.

Table 4: Cronbach's alpha coefficient of the dimensions of the instrument applied

\begin{tabular}{|c|c|c|c|c|c|}
\hline \multicolumn{2}{|c|}{ Reliability statistics } \\
\hline \multicolumn{2}{|c|}{$\begin{array}{c}\text { Factors that contribute to trust and } \\
\text { Use-of-the-RRSS }\end{array}$} & $\begin{array}{c}\text { confidence for the use of RRSS (Strategies } \\
\text { with social networks) }\end{array}$ & $\begin{array}{c}\text { RRSS-in-the-purchase- } \\
\text { intention }\end{array}$ \\
\hline $\begin{array}{c}\text { Cronbach's } \\
\text { alpha }\end{array}$ & N elements & Cronbach's alpha & N elements & $\begin{array}{c}\text { Cronbach's } \\
\text { alpha }\end{array}$ & $\begin{array}{c}\text { N } \\
\text { elements }\end{array}$ \\
\hline 0.941 & 18 & 0.865 & 13 & 0.833 & 5 \\
\hline
\end{tabular}

Source. Prepared

Based on the information gathered by implementing the surveys, the most outstanding findings will be presented in the results section, which answers the exposed approach, linking strategies with social networks with the consumer's intention of buying from tourism organizations, which this research considered as the restaurants in the gastronomic zone of Tijuana, Baja California.

\section{Results}

For the presentation of the main findings of the quantitative survey technique, it is essential to remember that it was applied to 378 consumers from five restaurants in the gastronomic zone of Tijuana Baja California, and that the instruments were distributed based on the number of users per month reported by managers of organizations where the questionnaire application was carried out.

Thus, in Figure 3 the results concerning the media used by respondents for acquiring information on services they wish to consume. $89.9 \%$ of the respondents said the Internet is the most consulted media, followed by the telephone with $50.3 \%$, and TV with $27.5 \%$. The latter being a one-way channel that can not receive feedback for decision-making on the product or service being consumed.

Figure 3: Means used to obtain information about the services they want to consume

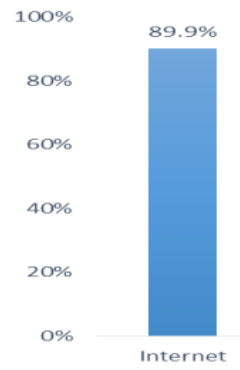

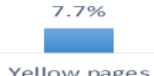
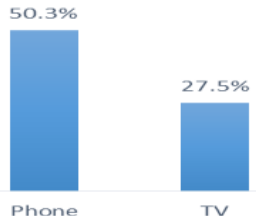

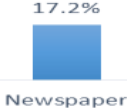

$\frac{1.3 \%}{\text { Others }}$

Source: Author's own elaboration. 
Also, Figure 4 shows the descriptive results indicating that the social network most used by respondents is Facebook with $89.9 \%$, followed by YouTube with $69.8 \%$, and Instagram with $51.3 \%$. Notably, despite the updates and new tools, Facebook is the most preferred by the population being studied.

Figure 4: Social networks used by the restaurants' clients

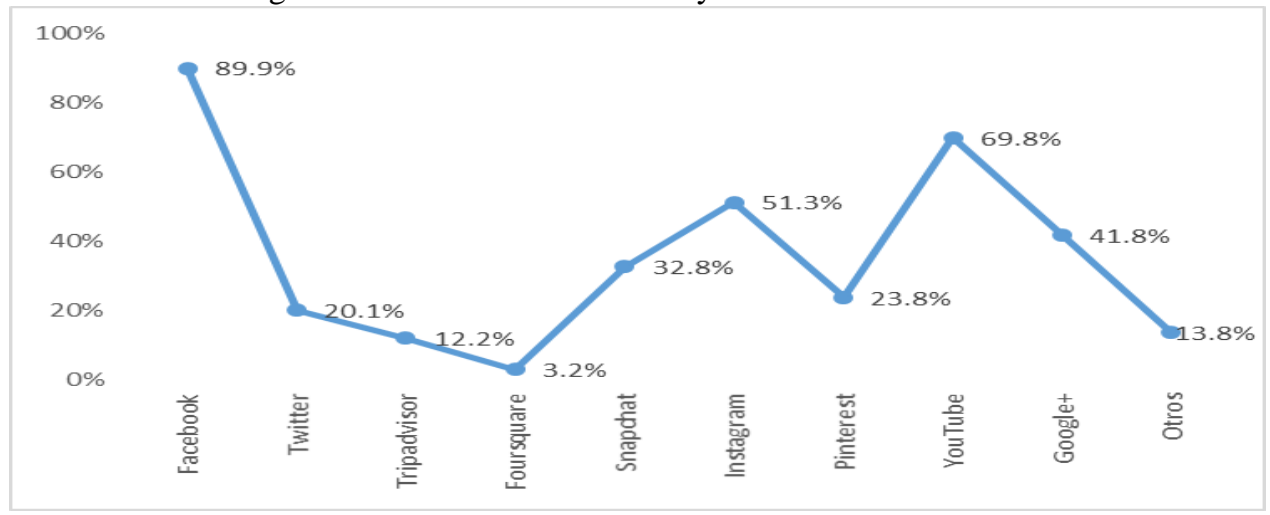

Source: Author's own elaboration.

Figure 5 shows the social network used for information regarding the restaurant to be visited at the next opportunity, Facebook is the most preferred among respondents with $71.2 \%$, followed by Google+ with $26.5 \%$, and Instagram with $24.6 \%$, which shows preference for Facebook from this population segment.

Figure 5: Social network they use to learn about the restaurants they will visit

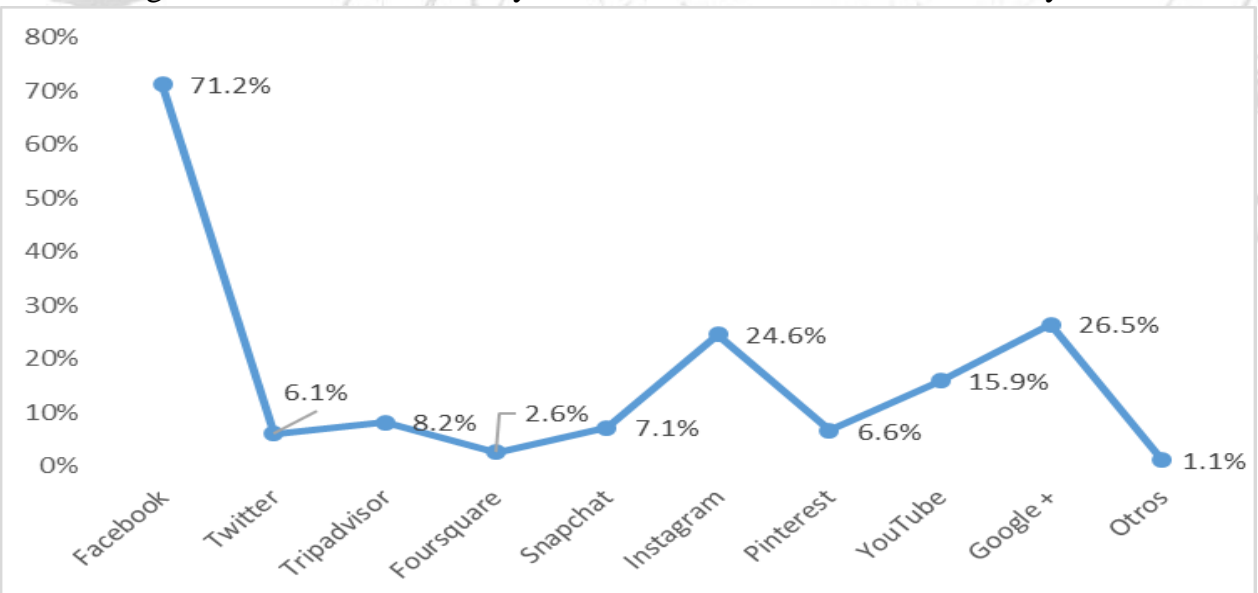

Source: Author's own elaboration.

Notably, based on the results obtained, $55.3 \%$ of respondents who use social networks consider this digital medium important for making the decision of choosing the restaurant to visit, which translates into an opportunity for tourism companies to promote the operational efficiency of this digital medium and achieve the goals that impact on customer satisfaction, attracting new customers through recommendations made by consumers and the audience that uses these tools.

The sum of the values corresponding strategies with social networks and the intention to purchase showed a positive average correlation, obtained based on the Pearson coefficient of 0.519 , significant at the 0.01 level, using the SPSS 20 program (Table 4). This indicates that social networks have become one of the elements that must be present in the corporate business strategy; therefore, it is added to the other factors that impact the consumer to purchase a tourist service. 
Table 4: Correlation: social networking strategies - Purchase decision Correlations

\begin{tabular}{|ll|r|r|}
\hline & & RRSS strategies & Purchase-intent \\
\hline RRSS & Pearson Correlation & 1 & $.519^{* * *}$ \\
Strategies & Sig. (Bilateral) & 301 & 000 \\
& $\mathrm{~N}$ & $0.519^{* * *}$ & 301 \\
\hline Purchase-intent & Pearson Correlation & .000 & 1 \\
& Sig. (Bilateral) & 301 & 303 \\
& $\mathrm{~N}$ & & \\
& & &
\end{tabular}

**. Correlation is significant at the 0.01 level (2-tailed).

Table 5 shows the correlation and determination coefficient (Table 5), which indicates that $26.9 \%$ of the purchase intention of the surveyed consumers is related to the social network strategies carried out by the businesses used in this research for the application of the instruments. This allows an analysis of the importance of implementing a plan that promotes trust and confidence in the users to resort to these digital media.

Table 5: Determination coefficient: Strategies with social networks - Decision to purchase Model summary

\begin{tabular}{|l|c|c|c|c|}
\hline Model & $\mathrm{R}$ & R squared & $\begin{array}{c}\text { R squared } \\
\text { adjusted }\end{array}$ & $\begin{array}{c}\text { Standard error of the } \\
\text { estimate }\end{array}$ \\
\hline 1 & $.519^{\mathrm{a}}$ & .269 & .267 & 1.018 \\
\hline
\end{tabular}

a. Predictors: (Constant), RRSS strategies.

Source: Author's own elaboration.

The results shown in Table 5 have a significance level of 0.01 according to the ANOVA test (Table 6). This allows us to take into account the association of the strategies with social networks in the consumers' intention to purchase from the tourist companies to which the instrument was applied.

Table 6: Significance level based en the ANOVA test

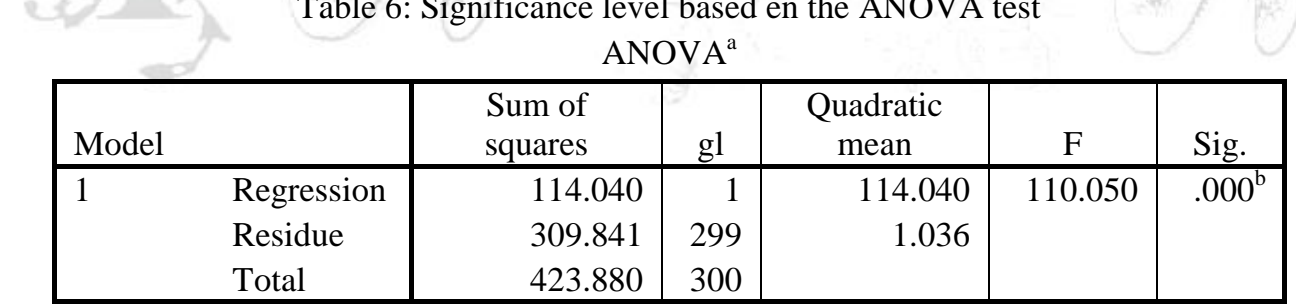

a. Dependent variable: Purchase-intent

b. Predictors: (Constant), RRSS strategies

Source: Own elaboration

\section{Discussion}

The evolution of social media causes people immersed in this technology to stop being mere receptors and turn into content collaborators that generate users, which has a direct impact on the increase of social networks usage. This allows the audience to express their opinions, becoming an attractive means to create a strategy that manages the relationship with consumers (Herrera, 2009; Hütt, 2012; Leal and Porras, 2015; UNWTO, 2016). The results obtained in the application of the quantitative instrument agree with what the authors express, since the Internet is the most consulted medium by consumers to whom the questionnaire was applied, having the advantage of accessing information in real time, as well as being able to link with 
multiple tools, which can be available to users to answer any questions they may have regarding the service or product they wish to obtain.

The results of the research show that more than $50 \%$ of respondents consider social networks as an important factor in the decision to purchase. In this way, Facebook is the tool that predominates in the population under study, both for everyday use and to look for information on the restaurant they could visit at the next opportunity. Sarmiento (2016), Andrade (2016), and Luna (2017) point out that customers have a need for showing their satisfaction through this technology by materializing their experience and sharing it with their friends or the general public, making the benefits received known. The flexibility of Facebook to carry out these actions is one of the reasons why people prefer this digital medium. It allows them to become carriers of the company's message and to express the value received through the work done by businesses through the Internet and in compliance with expectations once they enjoyed the expected benefit.

It should be noted that social networks have become a global phenomenon. The majority of the population of different social generations has found a way to obtain information on tourism services and / or products that they will consume on their next opportunity (Ruano, Congote and Torres, 2016; Santillan-Núñez, Velarde-Valdez, and Obombo-Magio, 2015; Altamirano et al, 2016). Also, through these technologies it is possible to access various alternatives and know their characteristics and current market offer (GutierrezLeefmans and Nava-Rogel, 2016; UNWTO, 2016). The results found in the research show preference towards the Internet over conventional options to obtain information, having as an advantage the proximity and speed that adapt to the needs of the user and making a decision based on the various alternatives found.

Through the ministerial summit of the World Tourism Organization (UNWTO) and the World Travel Market (WTM), ministers and executives of the private sector agreed that the creation of the brand of destinations and the operation of companies oriented to tourism marketing need to adapt to the changes induced by social networks, since the empowerment of consumers of these digital tools has completely transformed the way of making the strategies that positively impact the company and the image of the destination (SEGITTUR, 2015; UNWTO, 2015).

One of the main problems that companies go through to evaluate the impact of social networks is the planning of a period in which compliance with the objectives that justify the resources invested can be observed (Moliner et al., 2014; Rojas and Redondo, 2017). According to the results of the research, any initiative to be developed through social networks should be supported by a plan that adapts the strategies that suit the increase in the confidence and security of the people, and motivates them to frequently consult this means to confirm the services that are available to consumers, which obtain the benefits announced in the digital platform.

Likewise, Castello (2013), Miranda-Gonzalez et al (2015), Sarmiento (2016), and Luna (2017) highlight that social networks have become an element that contributes to the intention of purchase, and the trend in the use of tools Like Facebook, Instagram, YouTube, and other tools for the traveler increases each day. Associated with the results obtained in the research, it is essential to increase the quality of the service that is available to users, avoiding static positions without a project on the platforms used by restaurants. For this research, $26.9 \%$ of the purchase intention in the consumers surveyed is related to the strategies with social networks that companies are carrying out. It is important to highlight that the study units in this case are organizations that have aimed initiatives, and that the result is part of a comprehensive business plan.

\section{Conclusion}

Based on the results obtained in the Research, Internet is the medium most used by the people surveyed to learn about the services they wish to consume, replacing conventional media, which leads to a change in consumer habits and an area of opportunity for organizations that still refuse to commit to a plan in digital 
media. The risk of implementing initiatives without a process can derive a negative impact, because it is necessary to adapt the design, attributes, factors that increase the confidence and security that attract more followers, as well as the tools and the program to develop based on the audience or target market to which the project is directed.

According to the results obtained, the social network that most of the restaurants' consumers use is Facebook, followed by YouTube and Instagram. For searching restaurant information, Facebook predominates, but the second and third options are Google+ followed by Instagram, which is maintained in this same instance of preference by the users who visit these digital media. These are distinguished by the flexibility of interaction and adapt to the needs of the people who usually use these tools.

Likewise, more than $50 \%$ of the consumers surveyed indicate that they consider social networks important as part of the elements to be taken into account while deciding which restaurant to visit at the next opportunity. It is possible to find out through these digital media about the service and attention options received, through the comments that are usually made on the walls of these platforms. This may be the factor that the consumer needed in order to pursue or change their decision, since people will be anticipating an experience that meets their expectations.

Concerning the proposed hypothesis, the results allow assuring that there is an average correlation between the strategies with social networks and the purchase intention of the respondents. Other factors may be added to this (customer service, location, parking, etc.), which may be part of another investigation. In this way, the percentage of influence presented is obtained through the digital project carried out in organizations. It should be remembered that at the beginning of the research companies were selected because they demonstrated activity in these digital media and gave answers to the questions asked by the researcher, which allowed to obtain the study units that could contribute and demonstrate the incidence that this phenomenon currently has.

The research provides basic elements that must be addressed when implementing a strategy through social networks, which are the following: analyze the main needs of the company; select the tools that adapt to the users and / or segment to be captured; strategic plan containing the various stages in which the program will be developed (start> test $>$ adjustment of the strategy> maturity> first results > maintenance); be clear when presenting goals (create audience, customer satisfaction, purchase intention, etc.); evolve towards new projects or join efforts with loyalty programs or customer relationship management.

\section{References}

Abrego, D., Sánchez, y Medina, JM (2016). Influencia de los sistemas de información en los resultados organizacionales. Contaduría y Administración, (62), 303-320.

Aldape, KA, Abrego, D., y Medina, JM (2016). Análisis de la percepción de uso de las redes sociales como herramienta de marketing en las MiPYMES de Tamaulipas, México. Revista Ibérica de Sistemas y Tecnologías de Información, (18), 49-65.

Altamirano, VP, Túñez, JM, y Valarezo, KP (2016). Promoción turística 2.0. Análisis de las redes sociales de los gobiernos iberoamericanos. Opción, 32(9), 32-53.

AMIPCI. (2016). Asociación Mexicana de Internet. Estudio de Comercio Electrónico en México 2016., 156. Recuperado el 20 de $\quad$ octubre de 2017 de https://www.asociaciondeinternet.mx/es/component/remository/Comercio-Electronico/Estudio-deComercio-Electronico-en-Mexico-2016/lang,es-es/?Itemid=.

Andrade, DA (2016). Estrategias de marketing digital en la promoción de Marca Ciudad. Revista Escuela de Administración de Negocios (80), 59-72.

Azuela-Flores, JI (2011). Redes sociales en México, una reflexión. CienciaUAT, 5(4), 29-33.

Buhalis, D., y Law, R. (2008). Progress in information technology and tourism management: 20 years on and 10 years after the Internet_-The state of eTourism research. Tourism Management (29), 609-623. 
Castelló, A. (2013). Estrategias empresariales en la Web 2.0: las redes sociales online. San Vicente(Alicante). España.: ECU.

Coromoto, D., y Coromoto-Morillo, M. (2016). Influencia de la Comunicación Directa de las Agencias de Viaje en el Turismo Emisivo Merideño. SABER, 28(1), 125-136.

Cruz, I., y Miranda, AM (2016). La gestión de relaciones con el cliente: estrategia empresarial en una organización de servicios turísticos de Baja California. Revista Nacional de Administración, 7(2), 5979.

Daries-Ramon, N., Cristóbal-Fransi, E., Martin-Fuentes, E., y Marine-Roig, E. (2016). Adopción del Comercio Electrónico en el Turismo de Nieve y de Montaña: Análisis de la Presencia Web de las Estaciones de Esquí a Través del Modelo Emica. Cuadernos de Turismo (37), 113-134.

Farías, PC (2014). Estrategias de marketing utilizadas por las empresas chilenas para incrementar el valor de los clientes. Cuadernos de Administración, 30(51), 8-14.

Fischer, L., y Navarro, AE (2000). Introducción a la investigación de mercados. DF: McGraw-Hill.

Giraldo, CM, y Martínez, SM (2017). Análisis de la Actividad y Presencia en Facebook y otras Redes Sociales de los Portales Turísticos de las Comunidades Autónomas Españolas. Cuadernos de Turismo, 39, 239-264.

González-Valiente, CL (2014). Marketing, internet y redes sociales: repensando nociones de calidad de la información durante su proceso de gestión. Revista Capital Científico - Eletrônica (RCCe), 12(4), 124133.

Gutiérrez-Leefmans, C., y Nava-Rogel, RM (2016). Mercadotecnia digital y las pequeñas y medianas empresas.Enl@ce,13(1),45-61.

Hayes, B. (2012). Como medir la satisfacción del cliente. DF México: Alfaomega.

Herrera, H. (2009). Investigación sobre redes sociales y emprendimiento: revisión de la literatura y agenda futura. NNOVAR, 19(33), 34-50.

Hütt, H. (2012). Las Redes Sociales: Una Nueva Herramienta de Difusión. Reflexiones, 91(2), 121-128.

INADEM. (2017). Instituto Nacional del Emprendedor. Lo que debes saber de redes sociales, son útiles para tu Negocio. Disponible en: https://www.inadem.gob.mx/lo-que-debes-saber-de-redes-socialesson-utiles-para-tu-negocio [Acceso 9 octubre 2017].

Izquierdo, A., y Martínez, MP (2009). Análisis de los factores que condicionan la elección del canal de compra por parte del consumidor: evidencias empíricas en la industria hotelera. Cuadernos de Economía y Dirección de la Empresa, (41), 93-122.

Leal, R., y Porras, ST (2015). Oportunidades y riesgos de las redes sociales en internet: el caso de empresas mexicanas. Recherches En Sciences De Gestion, (111), 87-104.

Luna, G. (2017). La influencia del consumo simbólico en la intensidad de uso de las redes sociales digitales y el valor percibido de las experiencias. Innovar, 27(64), 37-50.

Martínez, SM, Bernal, JJ, y Mellinas, JP (2012). Los hoteles de la región de Murcia ante las redes sociales y la reputación online. Análisis Turístico, (13), 1-10.

Martínez-Valerio, L. (2012). Estrategias de promoción turística a través de Facebook. Palabra Clave, 15(2), 318-338.

Mendes, G., Augusto, A., y Gândara, JM (2013). Innovación en la promoción turística en medios y redes sociales. Estudios y Perspectivas en Turismo (22), $102-119$.

Miranda, AM, y Cruz, I. (2016). Redes sociales: herramienta de marketing internacional en el sector hotelero. El periplo sustentable, (31).

Miranda, AM, Cruz, I., Valle, MR, y Flores, JC (2015). Estrategias de marketing con redes sociales en hoteles de cuatro y cinco estrellas en la ciudad de Tijuana, Baja California. Teoría y Praxis, Edición especial, 10-31.

Miranda-González, FJ, Rubio, S., Chamorro, A., y Correia, SM (2015). Determinantes de la intención de uso de Facebook en el proceso de decisión de compra. Investigaciones Europeas de Dirección y Economía de la Empresa, 21(1), 26-34.

Moliner, B., Fuentes, M., y Gil, I. (2014). Las TIC como base de segmentación en el contexto B2B Turístico: Estudio aplicado en Hoteles Españoles. Revista de Análisis Turístico, 18(2), 19-31.

Namakforoosh, MN (2005). Metodología de la investigación (2da. ed.). México: Limusa. 
OMT. (2015). Cumbre Ministerial OMT/WTM: redes sociales y tendencias en la creación de marca de los destinos. Disponible en: http://media.unwto.org/es/press-release/2015-11-05/cumbre-ministerialomtwtm-redes-sociales-y-tendencias-en-la-creacion-de-mar [Acceso 4 noviembre 2017].

OMT. (2016). Organización Mundial del Turismo: Impacto de las nuevas tecnologías en el sector turístico. Disponible en: http://media.unwto.org/es/press-release/2016-06-10/la-omt-aborda-en-japon-elimpacto-de-las-nuevas-tecnologias-en-el-sector-tu [Acceso 27 noviembre de 2017].

Pinto de Farias, TR, Costa, JH, y Costa Perinotto, AR (2017). Empresas Turísticas, Redes Sociales y Negocios Electrónicos. Estudios y Perspectivas en Turismo, 26, 626-643.

Prada, R. (2016). Las TIC, factor de efectividad en la aplicación del mercadeo digital en negocios de retail. Revista Escuela de Administración de Negocios, (80), 105-115.

Richardson, N., Gosnay, R., y Carroll, A. (2014). Guía de acceso rápido al marketing en Redes Sociales: marketing de alto impacto y bajo costo que sí funciona. ebook: Granica.

Rodríguez, L., Fraiz, JA, y Ramos, D. (2015). Las Agencias de Viajes ante la influencia de las Redes Sociales en el turismo. El caso de Ourense. Pasos, 13(4), 829-836.

Rojas López, MD, Arango, P., y Gallego, JP (2009). Confianza para efectuar compras por Internet. Dyna, 76(160), 263-272.

Rojas, P., y Redondo, M. (2017). Como monetizar las redes sociales. Madrid, España: LID EDITORIAL.

Ruano, LE, Congote, EL, y Torres, AE (2016). Comunicación e interacción por el uso de dispositivos tecnológicos y redes sociales virtuales en estudiantes universitarios. Revista Ibérica de Sistemas y Tecnologías de Información, (19), 15-31.

Ruiz, C., y Sanz, S. (2006). Explaining Internet dependency: an exploratory study of Spanish web-users. Internet Research, 16(4), 380-397.

Santillán-Núñez, MA, Velarde-Valdez, M., y Obombo-Magio, K. (2015). Tecnologías de Información y Comunicación al servicio del turismo en Mazatlán, Sinaloa, México. Ciencias Holguín, 11(1), 1-10.

Sarmiento, JR (2016). El Impacto de los medios sociales en la estructura del sistema de distribución turístico: análisis y clasificación de los nuevos proveedores de servicios turísticos en el entorno online. Cuadernos de Turismo (38), 459-483.

SECTUR. (2014). Análisis Integral del Turismo. Boletín cuatrimestral de Turismo-DATATUR (40), 1-66. Disponible en: http://www.datatur.sectur.gob.mx/documentos\%20publicaciones/bct_no40final.pdf1-66 [Acceso 9 octubre 2017].

SECTUR. (2016). Impulsan la actividad Turística nuevas tecnologías y la digitalización. Disponible en: http://www.gob.mx/sectur/prensa/impulsan-la-actividad-turistica-nuevas-tecnologias-y-la-digitalizacion-de-la-madrid [Acceso 15 octubre 2017].

SEGITTUR. (2015). Informe destinos turísticos inteligentes: Construyendo el futuro. Madrid, España. Disponible http://www.segittur.es/opencms/export/sites/segitur/.content/galerias/descargas/documentos/LibroDestinos-Inteligentes-en-Espaol.pdf [Acceso 2 noviembre 2017].

Sixto, J. (2015). Desarrollo de las redes sociales como herramienta de marketing. Anagramas Rumbos y Sentidos de la Comunicación, 13(26), 179-196.

Uribe, F., Rialp, J., y Llonch, J. (2013). El uso de las redes sociales digitales como herramienta de marketing en el desempeño empresarial. Cuad. admon.ser.organ., 26(47), 205-231.

Valenzuela, L., y Martínez, C. (2015). Orientación al Cliente, Tecnologías de Información y Desempeño Organizacional: Caso empresa de consumo masivo en Chile. Revista Venezolana de Gerencia, 20 (70), 334-352. 